\title{
An unexpected case of heterospecific altruistic behaviour in a non-breeding migrant tern (Charadriformes, Sternidae)
}

\author{
Giacomo Bruni ${ }^{1}$, Mattia Menchetti ${ }^{1 *}$, Giulia Ricciardi ${ }^{1}$, Andrea \\ $\mathrm{VANNINI}^{2}$ \& EMILIANO MORI ${ }^{3}$
}

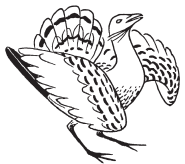

Giacomo Bruni, Mattia Menchetti, Giulia Ricciardi, Andrea Vannini \& Emiliano Mori 2014. An unexpected case of heterospecific altruistic behaviour in a non-breeding migrant tern (Charadriformes, Sternidae). - Ornis Hungarica 22(1): 76-80. \begin{abstract}
been reported in many publications. However, the benefits of the altruistic behaviour are not easy to understand, as benefits and costs of this behaviour have been poorly identified. In May 2013, in a wetland in Central Italy (Piana Fiorentina, Tuscany), some cases of interspecific feeding of an Eurasian Coot Fulica atra chick by an adult non breeding Whiskered Tern Chlidonias hybrida were witnessed. We suggest that the behaviour of the Tern was triggered by the begging of the chick or by its own hormonal status.
\end{abstract}

Keywords: interspecific feeding, Fulica atra, Chlidonias hybrida, chicks

Összefoglalás A más fajok fiókáit etető madarakról számos beszámolót publikáltak az ornitológiai szakirodalomban. Azonban evolúciós szempontból az ilyen altruisztikus viselkedés értelmezése nehéz feladat, ugyanis az önzetlen egyed számára a viselkedés előnye még kevéssé ismert. Egy közép-olaszországi (Piana Fiorentina, Toszkána) vizes élőhelyen 2013 májusában több alkalommal megfigyeltük, hogy szárcsa (Fulica atra) fiókát etetett egy kifejlett, de nem költő fattyúszerkő (Chlidonias hybrida). Véleményünk szerint a szerkő viselkedését a szárcsa fióka kéregetése, vagy a saját hormonális állapota válthatta ki.

Kulcsszavak: interspecifikus etetés, Fulica atra, Chlidonias hybrida, fiókák

${ }^{1}$ Department of Biology, University of Florence, Via Madonna del Piano, 6 - 50019 Sesto Fiorentino (Florence), Italy,e-mail:mattiamen@gmail.com

${ }^{2}$ Environmental Biologist, Landscape Ecologist, via Pompeo Ciotti 60/2 - 59100 Prato, Italy

${ }^{3}$ Di.S.A.F.A., Entomology and Zoology, University of Turin, Via Leonardo da Vinci, 44 - 10095 Grugliasco (Turin)

*corresponding author

\section{Introduction}

Feeding of the chicks or fledglings of other species has frequently been observed in birds (Shy 1982, Koenig 1988), and is not easily explained by evolutionary theory. In her review, Shy (1982) tried to define the possible ethological mechanisms underlying these behaviours. In most cases, both species involved in these displays are breeding in the same area (McNair \& Duyck 1991, Dróżdż et al. 2004) and interspecific altruistic behaviour might decrease competition for nesting sites ('mixed clutches' if idoneous/suitable net sites represent limiting resources) or be due to loss of the clutch by one of the two species and/or proximity between nests of the two species (Shy 1982).

Whiskered Tern Chlidonias hybrida is a polytypic sub-cosmopolitan species (Cramp 
\& Simmons 1980, IUCN 2012) with migratory habits (Cramp \& Simmons 1980, Svensson 2009). Distribution range is highly fragmented (Spina \& Volponi 2008). European populations winter mainly in tropical West Africa (Cramp \& Simmons 1980, Spina $\&$ Volponi 2008), although there are known cases of wintering in Mediterranean areas (Spain, Algeria, Tunisia) (Cramp \& Simmons 1980). Nesting takes place in colonies of various size (Cramp \& Simmons 1980), and exclusively in flooded areas (e.g. marshes), characterised by the presence of aquatic plants appearing on the surface (Spina \& Volponi 2008, IUCN 2012). The diet is carnivorous (e.g. fishes, frogs and macroinvertebrates) (Cramp \& Simmons 1980, IUCN 2012). As for Italy, the species is classified as regular migratory, wintering and irregular breeding (Tinarelli 2006, Spina \& Volponi 2008). C. hybrida is declining all over the Europe (SPEC3: Tucker \& Heath 1994); as for Italy, it is classified as 'vulnerable' by the Red List of breeding birds (Peronace et al. 2012), as nesting sites are located only within Emilia-Romagna Region (Frugis et al. 1978, Tinarelli 2006). Whiskered Terns are known to nest near other species' nests (Cramp \& Simmons 1980), and cases of conspecific nest parasitism were also reported (Yom Tov 2001, Paillison et al. 2008). However, heterospecific altruistic behaviour had never been recorded for this species. In this note, we describe observations of an adult non-breeding Whiskered Tern feeding a Eurasian Coot chick and speculate on possible causes of this enigmatic behaviour.

\section{Materials and Methods}

Observations, done by photographers and birdwatchers, who regularly frequent the area, took place from a bird-watching hut, in the Natural Area of Local Interest (ANPIL) 'Podere La Querciola', located in Piana Fiorentina (Tuscany, Central Italy). The study-wetland $\left(43.824558^{\circ} \mathrm{N}, 11.172574^{\circ}\right.$ E; c. 50 ha large) has been described in details by Bruni et al. (2013). Fish species present in these ponds include Gambusia holbrooki and Pseudorasbora parva. F. atra is a known breeding species in this site (Bruni et al. 2013), whereas this work report for the first time the presence of the Whiskered Tern (a single individual) in Piana Fiorentina. This tern species is listed as regular migrant in Tuscany (Tellini Florenzano et al. 1997): observations of C. hybrida in this region belong to migrant individuals during the route from the African wintering site to the breeding sites (e.g. Northern Italy: Frugis et al. 1978, Tinarelli 2006, Spina $\&$ Volponi 2008). The individual of $C$. hybrida stayed in the study site from $18^{\text {th }}$ to $23^{\text {rd }}$ May 2013, doing its feeding activity in one of the four lakes (named Lago della Querciola). Two nests (with two and four nestlings respectively) of Eurasian Coot are present in the part visited by the Tern.

\section{Results}

On $20^{\text {th }}$ May (h. 17:45), the Whiskered Tern caught a fish, and then stopped on a perch without swallowing the prey. After a few seconds, it flew towards a little islet where two Coot chicks were present, hidden by bulrushes (Juncus sp., Cyperaceae). The Tern approached the bulrushes twice, then dropped the fish. Adult Coots were not observed in the surroundings. The day after (21 $1^{\text {st }}$ May, h. 8:00-11:00), the Whiskered Tern tried to approach two Coot chicks many times, hovering above them while 
holding fishes in its beak. Some preys were dropped towards the chicks, others eaten by the Tern itself on a perch. In the meanwhile, parents stood near the chicks, showing no concern about the behaviour of the Whiskered Tern. Then, on 22 ${ }^{\text {th }}$ May (14:00), two Coot chicks were swimming around the smallest islet of the lake and one adult individual was about two meters from them. The Whiskered Tern was fishing, resting sometimes on two perches. Once it caught a $P$. parva, the Whiskered Tern approached one of the chicks, extending the beak with the prey towards it (Figure 1a, 1b). The chick responded with a defence posture, raising its legs towards the Whiskered Tern (Figure 1c), which dropped the prey. Then, the chick ate the fish (Figure 1d).
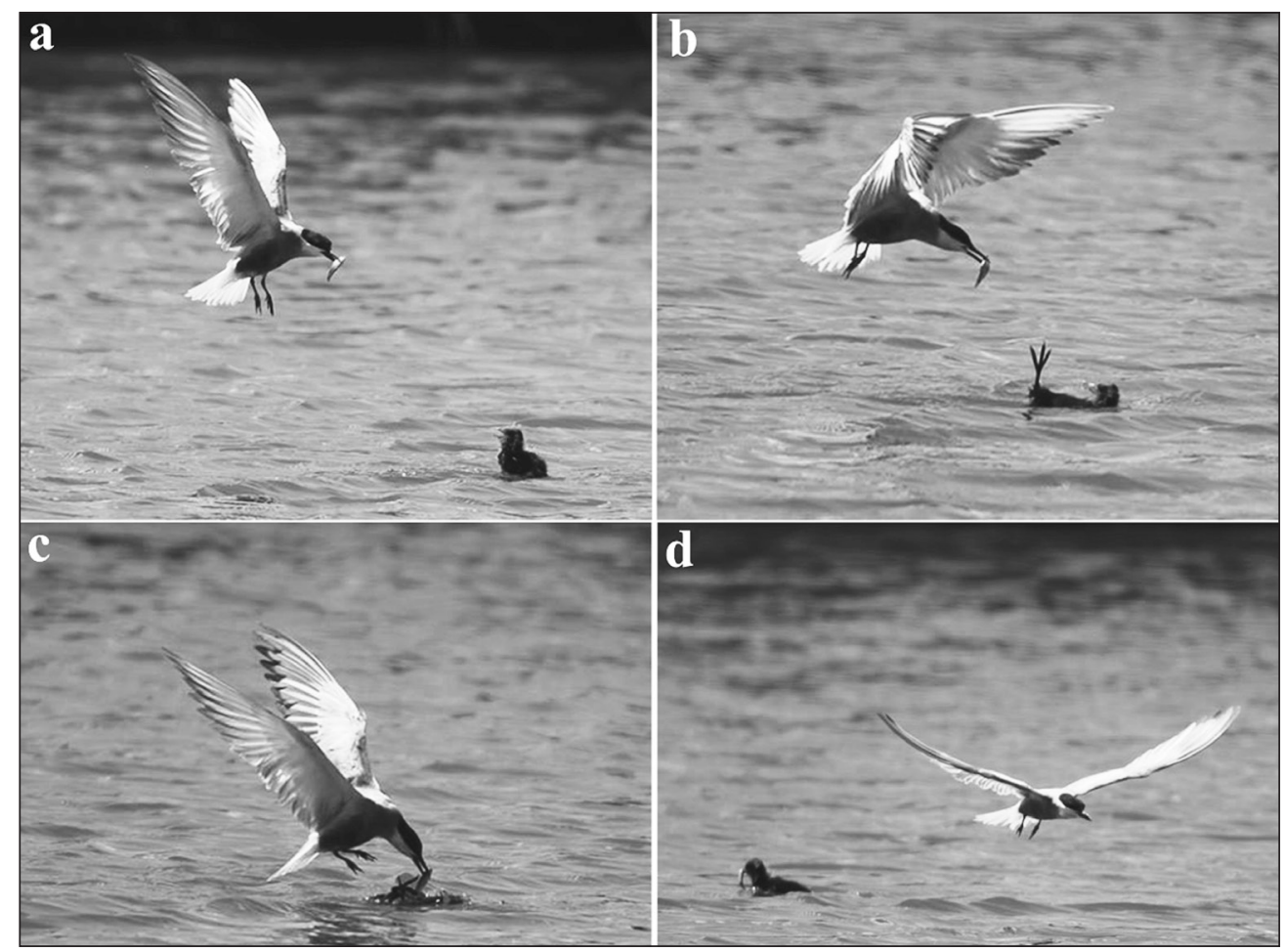

Figure 1. Whiskered Tern feeding the chick of Eurasian Coot with a Pseudorasbora parva

1. ábra Fattyúszerkő szárcsa fiókát etet kínai razbórával (Pseudorasbora parva)

\section{Discussion}

Altruistic behaviours displayed by another tern species (i.e. Sterna hirundo) are recorded in literature only for a breeding population, whose nests were localised in the proximity of a breeding colony of European Herring Gull Larus argentatus (Kuhlemann 1939). Although Whiskered Terns do not reproduce in Tuscany, this observation fall into the breeding period of the species in Europe (Paillison et al. 2006, Paillison et al. 2007), and the individual observed in Piana Fiorentina was considered to be an adult, according to the colours of the plumage (Cramp $\&$ Simmons 1980). Moreover, it is likely that this individual observed in Piana Fiorentina was on route to reach the only Italian bree-

\section{(photo Alessandro Piazzini). Chronology reflect the alphabetical sequence of letters}


ding area; this means that its hormonal status was close to that experiences during breeding, and may have elicited the altruistic behaviour described here (e.g. Buntin 1996). Moreover, the colonial status of the tern species would favour social intra - but also inter - specific interactions. It is noteworthy that the behaviour of the Coot chick mimics that of Whiskered Tern chicks that often go away from the nest (Cramp \& Simmons 1980). Coots are omnivorous, eating mainly plant material, but also consume small fishes (Cramp \& Simmons 1980), thus, the behaviour of Coot chicks could mimic that of Whiskered Tern chicks. Hence these observations would be considered as a kind of interspecific begging trials. Although chicks of $C$. hybrida and $F$. atra are markedly different both in physical aspects and in voices (Cramp \& Simmons 1980), this interspecific feeding could also be explained as a response

\section{References}

Bruni, G., Boggiano, F., Menchetti, M. \& Mori, M. 2013. First report of egg predation by an unpaired Eurasian Coot, Fulica atra, L., 1758 (Aves: Gruiformes) on Black-winged Stilt, Himantopus himantopus, L., 1758 (Aves: Charadriiformes): one case from central Italy. - Italian Journal of Zoology 80: 313-316.

Buntin, J. D. 1996. Neural and hormonal control of parental behavior in birds. - Advanced Studies in Behaviour 25: 161-213.

Cramp, S. \& Simmons, K. E. L. 1980. The Birds of the Western Palearctic. Vol. 2. - Oxford University Press, New York, USA, pp. 695

Dróżdż, R., Hromada, M. \& Tryjanowski, P. 2004. Interspecific feeding of a Great Grey Shrike (Lanius excubitor) fledgling by adult Yellowhammers (Emberiza citrinella). - Biological Letters 41: $185-187$.

Frugis, S., Spina, F. \& Zanichelli, F. 1978. La biologia riproduttiva del mignattino piombato (Chlidonias hybrida) [The breeding biology of the Whiskered Tern (Chlidonias hybrida)]. - Bollettino di Zoologia 45: 23. (in Italian)

Koenig, W. D. 1988. Reciprocal altruism in birds: a critical review. - Ethology and Sociobiology 9: 73-84. to the begging of the chick of $F$. atra, which represents a known feeding stimulus in birds (Shy 1982, Dróżdż et al. 2004).

Shy (1982) and Trombino (1999) claimed also that mateless/non-breeding heterospecific adults may gain experience by feeding chicks of other species, increasing the probability of pairing in the next breeding season.

\section{Acknowledgements}

The authors would like to thank S. Guidotti and F. Guiggiani, for their valuable help in data collection, and A. Piazzini, who provided us with the photo of the Whiskered Tern. O. Melaiu kindly revised and improved the English of the manuscript. Two anonymous referees and the Editor kindly provided significant comments on the initial draft.

Kuhlemann, P. 1939. Beobachtungen an einer durch Flusseeschwalben (Sterna hirundo) aus vertauschtem Ei erbrüteten und aufgezogen Silbermove (Larus argentatus) [Observations on a Common Tern (Sterna hirundo) egg hatched and raised by a Herring Gull (Larus argentatus)]. - Zeitschrift fur Tierpsychologie 3: 75-84. (in German)

International Union for Conservation of Nature 2012. Red List of Threatened species - Chlidonias hybrida. - Available online (Accessed on $1^{\text {st }}$ June 2013)

McNair, D. B. \& Duyck, B. 1991. Interspecific feeding among some oscines. - Chat 55: 9-11.

Paillisson, J. M., Reeber, S., Carpentier, A. \& Marion, L. 2006. Plant-water regime management in a wetland: consequences for a floating vegetation-nesting bird, Whiskered Tern, Chlidonias hybridus. Biodiversity and Conservation 15: 3469-3480.

Paillisson, J. M., Reeber, S., Carpentier, A. \& Marion, L. 2007. Reproductive parameters in relation to food supply in the Whiskered Tern, Chlidonias hybrida. - Journal of Ornithology 148: 69-77.

Paillisson, J. M., Latraube, F., Marion, J. \& Bertagnolle, V. 2008. Indirect evidence of conspecific nest parasitism in the colonial Whiskered Tern 
(Chlidonias hybrida). - Comptes Rendus Biologies 331: 559-567.

Peronace, V., Cecere, J. G., Giustin, M. \& Rondinini, C. 2012. Lista Rossa 2011 degli Uccelli nidificanti in Italia [Red list 2011 of breeding birds in Italy]. - Avocetta 36: 11-58. (in Italian with English Summary)

Shy, M. M. 1982. Interspecific feeding among birds: a review. - Journal of Field Ornithology 53: 370393.

Spina, F. \& Volponi, S. 2008. Mignattino Piombato (Chlydionias hybrida) [062560]. - In: Atlante della migrazione degli Uccelli in Italia. 1. Non-Passeriformi [Atlas of migration of Birds in Italy]. - Ministero dell'Ambiente e della Tutela del Territorio e del Mare, Istituto Superiore per la Protezione e la Ricerca Ambientale (ISPRA), Roma, Italy, pp. 684-686. (in Italian with English Summary)

Svensson, L. 2009. Collins bird guide. - HarperCollins Publishers Ltd., pp. 448

Tellini Florenzano, G., Arcamone, E., Baccetti, N., Meschini, E. \& Sposimo, P. 1997. Atlante degli
Uccelli nidificanti e svernanti in Toscana (19821992) [Atlas of breeding and wintering birds in Tuscany (1982-1992)]. - Quaderni del Museo di Storia Naturale di Livorno - Monografie 1. (in Italian)

Tinarelli, R. 2006. Dinamica della popolazione nidificante e conservazione del Mignattino piombato Chlidonias hybrida in Italia [Population dynamics and conservation of breeding Whiskered Tern Chlidonias hybrida in Italy]. - Picus 32: 67-73. (in Italian with English Summary)

Tucker, G. M. \& Heath, M. F. 1994. Birds in Europe: their Conservation Status. - BirdLife International (BirdLife Conservation Series 3), Cambridge, UK, pp. 600

Trombino, T. 1999. Helping behaviour within Sapsuckers (Sphyrapicus spp.). - Wilson Bulletin 112: 273-275.

Yom-Tov, Y. 2001. An updated list and some comments on the occurrence of intraspecific nest parasitism in birds. - Ibis 143: 133-143.

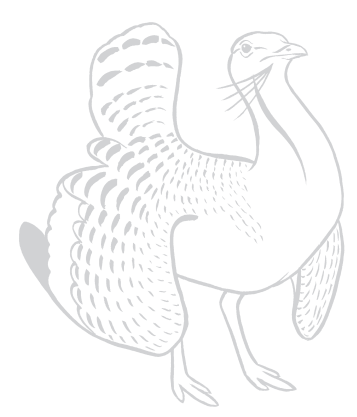

